\title{
Treating the fiction of forms: Metafiction in John Barth
}

\author{
Goetz Egloff ${ }^{1,2}$ \\ ${ }^{1}$ Coeditor, Yearbook of Psychohistorical Research, Heidelberg, Germany \\ ${ }^{2}$ Practice for Psychoanalysis, Mannheim, affil, University of Heidelberg, Heidelberg, Germany
}

\section{Email address:}

goetz.egloff@alumni.uni-heidelberg.de,g.egloff.medpsych.ma@email.de

\section{To cite this article:}

Goetz Egloff. Treating the Fiction of Forms: Metafiction in John Barth. International Journal of Literature and Arts. Vol. 2, No. 1, 2014, pp. 1-5. doi: 10.11648/j.ijla.20140201.11

\begin{abstract}
The essay depicts John Barth's sophisticated dealing with the fiction of forms. By referring to short stories from his 1968 collection Lost in the Funhouse, and especially to "Life-Story", Barth's approach of creating metafiction as response to supposedly exhausted literary topics is highlighted. Fiction, consisting of forms as equivalent of existence in being, and consisting of thoughts as equivalent of essence in being, cannot basically change until essence in being itself will change. As forms will only repeat again and again, Barth challenges the reader by having him witness the demanding process of creating a work of art. Varying the kuenstlerroman, he anticipates identity issues of subsequent decades as well as issues of being and art.
\end{abstract}

Keywords: John Barth, Metafiction, Fiction of Forms, Essence, Existence, Short Story

\section{Turning Away from Plot in the Short Story}

While the early 'tall tales' had shaped the image of man in stories for authors to come, authors of the 'American hero' in spite of their optimism as an expression of proven confidence in their own power and in spite of humor as an attitude toward a reality experienced as conquerable had to recognize the complexity of life. (1) After skepticism about superficial optimism and passed-on societal behavioral codes and attitudes had been enunciated by the 'dark authors', like Poe and Melville, in the nineteenth century, now psychological aspects of life were focused on. With that, a dynamic plot became overshadowed in favor of a static episode depicting e.g. a part of daily routine. The subject matter would often be the experiencing of a complex reality by an inexperienced character. (2)

In the short story genre, "(...) the techniques of representation stem not from realism, which emulates reportage, but from symbolism, which descends from poetry." (3) A traditional linear development, like events happening realistically, or in causality, coming to a crisis and leading to denouement, gave way not only to psychographs but to an increasing use of symbol modes. Moreover, "In the new short story (...), the epiphany is abolished, and the writer's theme or perception is diffused throughout the work, which becomes, in effect, a succession of revelatory moments." (4)

In high modernism of the 1920s, authors like Hemingway and Faulkner had their protagonists act apparently free of plot, yet endowing any details with significance. Later on, authors like Salinger and Mary McCarthy in the 1940s aligned themselves with plot. The inability of mastering the realities of existence was put in moral context. Individual moral shortcomings were also depicted by authors like Bellow and Flannery O'Connor in the 1950s. While readers of these works now could identify with the characters, the 1960s would confront them with modernistic traits again. "In these works, the narrative is more discontinuous and the chronology even more distorted (...). Rather than push his characters through a plot, the author fills in the picture, often his (and the reader's) attitude towards the scene." (5) Fragmented time and thought, setting changes and mood changes now constituted the story, so that it "(...) sometimes gives the impression that it could go on forever (...)." (6) With that, gaining knowledge got into foreground as well as the thinking process itself did, leading the protagonists to discovering of complex connections.

\section{Barth's Involvement with the Fiction of Forms: "Life-Story"}

John Barth's existentialistic approach in the short story genre is to be understood as a reaction on the supposed 
exhaustion of topics in literature. Fiction, on the one hand consisting of forms - as equivalent of existence in being, on the other hand consisting of thoughts - as equivalent of essence in being, cannot basically change until essence in being itself will change. The notion of thought in fiction applies to the notion of essence in being. (7) "The ideas of fiction are those essential qualities which define and characterize it. They are aspects of the essence of being human." (8) Supposedly the condition of being will not change; the notion of thought in fiction will not change either. Forms in fiction may change, analogously to the changing of the phenomenal images of being. It is just the outer images that change, not the forms. Forms will only repeat again and again. "The fiction of forms is fiction that imitates other fiction." (9) Thus, the very first story ever written is the legacy the author has to come to terms with. It leaves only imitation to the author. "The fiction of forms at one level simply accepts the legacy and repeats the form bequeathed it, satisfying an audience that wants this familiarity." (10) The fiction of forms may be aware of this, still it is trapped in that entity of forms. Parody may be an attempt to escape from it, mostly "(...) in a parasitic relationship to romance. It feeds off the organism it attacks and precipitates their mutual destruction." (11) Romance as fiction of forms - is the root of all deliverance of stories.

Barth, assuming that any identity can only be fictional as objective reality does not exist, in his 1968 short story "Life-Story" (12) reflects on this idea by questioning any 'real' identity of the author-narrator. He, the author-narrator, in his attempt of beginning to tell a story, given he himself is fictional, wonders if he is to be the character of whom the reader will be informed that he is about to write a story without writing it as he himself is merely fictional and with that, as it were, 'being written'. Through this reflection Barth hints at the artificiality of the produce that is called literature; he plays with reception expectations. In searching for some "ground-situation" and reflecting on "(...) heroes I can admire, heroines I can love (...)" (13) the author-narrator is conscious of the expected; yet he is subjected to the conflict that he shall not fulfill these expectations although he is forced to fulfill the convention. But conscious of the convention he may violate it willfully. The mere chance of telling a story is assessed the topic to be told. Obviously, the issue of the artist's identity is at stake here. The reader is confronted with it by not being fulfilled their expectations, instead they are elaborated on in parody. At the same time the kuenstlerroman, or entwicklungsroman, is parodied by not depicting an artist experiencing development but depicting an artist reflecting on the understood. Barth has the reader be informed about being conscious about that as the central motif. The author-narrator occasionally refers to Scheherazade (14) who while telling her story becomes part of the story being told. "Scheherazade represents Barth's exemplary model for the relevance of the frame tale for the artist: like the artist, she tells all the stories, at the same time becoming the story-teller in the text." (15) Thus, the matter of concern is the creation of the work of art, i.e. the act of writing. In "The Thousand Nights and a Night", storytelling itself is what Barth's author-narrator refers to as "vehicle-situation" (16); still the "ground-situation" generating a "vehicle-situation" is missing. This fact constitutes the "ground-situation"; it is like being an artist in a one way street of the prevailing condition of creating a work of art. This is to be understood metaphorically, the metaphors referring to something, not representing themselves.

The nouveau roman is brought into the equation; its disassembling of the novel's traditional functions by thematizing itself (17) is hinted at in the author-narrator's referring to the " $(\ldots)$ most prolix and pedestrian 'tranche-de-vie' realism, unredeemed by even the limited virtues of colorful squalor, solid specification, an engaging variety of scenes and characters, in a word a bore (...)." (18) According to Robbe-Grillet, the "tranche-de-vie realism" of the roman balzacien stems from bourgeoisie and is advocating an inappropriate picture of reality. (19) Even a non-Marxian approach like deconstruction might render similar results; breaking traditional perspectives might serve as an act of emancipation. (20) Actually, the bourgeois view was met by breaking conventions and e.g. having the text reflect on itself. Institutionalizing of breaking traditions even brought about the creation of a novel depicting its mere working as a novel. (21) This auto-mimetic approach rejects 'classic' depiction in literature; yet this rejection will have to be met by depiction of rejection. Any onslaught on depiction will have to make use of further depiction - apparently an issue that has been crucial in postmodernity at any rate. (22) Again, this contradiction addresses the issue at stake: the reader is hinted at it directly - as central motif in the text, then indirectly - as text in its entirety as well as in relation to traditional texts. Pushing it even further, literature might serve as mere depicting agent of its own artificiality. "Am I being strung out in this ad libitum fashion I wondered merely to keep my author from the pistol?" (23) Here, Barth has the author-narrator - who in his being fictional has to have his own author - ask the existential question, substituting Barth himself. It is the question of meaning, purpose and rationale of his existence and of literature itself. $\mathrm{He}$ might even be in an "ad libitum fashion", an improvisational mode potentially compromising the 'substance' of the text to be created. Wondering what made him sure it is no movie or theater play he is in the text says: "Because U responded while he certainly felt rather often that he was merely acting his own role or roles he had no idea who the actor was (...)." (24) The inner dialogue shows the author-narrator reflecting on the issue of his role, indirectly addressing reader reception: whereas the reader reads a story about the creation of a story, the author-narrator is not sure about his own function in this creation, yet he is conscious of this fact. Moreover, the existential issue is put in context with the medium in general: "He rather suspected that the medium and genre in which he worked - the only ones for which he felt any vocation - were moribund if not already dead." (25) But fiction in decline stands for society: 
"He rather suspected that the society in which he persistedthe only one with which he felt any degree of identification was moribund if not et cetera." (26) The syntax structure returns abridged the more his reflections are narrowing on a personal level - leading to a bodily perspective - and broadening on a universal level at the same time. From literature to medium to society to individual being, the circle becomes more and more constricting. This circle, beginning with the loss of thoughts, culminates in addressing physical substance: "He knew beyond any doubt that the body which he inhabitated - the only one et cetera - was et cetera." (27) This is climaxing and anti-climaxing at the same time. Stupendously or not, the author-narrator is pleased by his loss of thoughts, maybe this is due to reflecting his loss of thoughts as a fact of creating new thought. Those abridged thoughts mirror the endlessly reflected facts that - no matter what they refer to - always lead to the same results. Being pleased ("The idea pleased him.") (28) goes into decline, though. After the last constriction (the reflection of the moribund onto his own body) this thought is not articulated anymore ("The idea et cetera.") (29) Even this train of thought of pleasure or satisfaction about finiteness and transience is in itself a mirroring of the ever same result, namely the fact that whatever he may think, it will always be an imitation of the preceding. Even assessing this fact is imitation. That is why objective reality cannot exist.

Here, the kuenstlerroman or entwicklungsroman issue is varied in a new, postmodernistic manner. "(...) by introducing himself as protagonist of his own text, the writer proposes a distance from his former self. The artist, knowing himself to be an artist, devises his own Bildung in retrospect." (30) The very way how he does it is new as it has to do with the concept of the blank. The author-narrator in "Life-Story" has left the process of his becoming aware of the issues at stake behind; the story itself mirroring this fact through redundant syntax. His autobiographical paradox his former self in relation to his present self - (31) is not created within the story but subject of the story. It can almost be seen as an artifact of human history. "Was the novel of his life for example a roman à clef?" (32) The author-narrator approaches the issue of his existence from the viewpoint of fiction: might some author of Barth's have written his own "Life-Story"? If so: in the shape of a novel with 'real' persons and 'real' actions? This question Barth approaches with disdain of the genre, referring to the lack of ability to reflect in the potential characters of a roman à clef; the question remains unanswered. (33) Equally unanswered for the author-narrator is the beginning of the story, any 'his' referring to himself (the story of his life) as well as to any potential author (the one who writes the life story about him). (34) Following shortly he words his displeasure about that by parodying his initially introduced statement of the idea that he might be fictional, making it the target of his mockery: "God so to speak spare his readers from heavy-footed forced expositions of the sort that begin in the countryside near __ in May of the year___ it occurred to the novelist that his own life might be a was the leading or an accessory character." (35) This fiction-irony expresses pessimism toward the story to be created; again the author-narrator, conscious of the conventions, breaks them by telling the reader about his own reaction on a literary genre. He practically neutralizes the text's character, disassembling it by a statement that generally might only be made after reception of the text. He withdraws by reflecting on reception expectations, depicting metafictionality while making fun of it.

\section{Variations of the Blank in Barth's Metafiction}

"Beginning: in the middle, past the middle, nearer three-quarters done, waiting for the end." (36) The first sentence of the short story "Title", (37) making one of a few companion pieces to "Life-Story" and published in the story collection Lost in the Funhouse, once more thematically relates to the issue of storytelling. Again the narrative genre and its traditional functioning is pointed at, again the narrator steps out of his traditional position before the story (the story he is in and the story he is about to write) can develop. Since he fails to develop the story, the narrator's consciousness, like in "Life-Story", is put at the center of interest. His reflection, "The worst is to come. Everything leads to nothing: (...) The final question is, Can nothing be made meaningful?", (37) shows the narrator conscious of his supposed blank of thoughts in a fashion similar to the author-narrator in "Life-Story", stating medium and being in decline and putting 'et cetera' as reflecting agent of the blank. The narrator in "Title" directly uses 'blank' as expression of the blank, even choosing the technical term 'title' as a heading, again a metaphor not representing itself. Being in an inner dialogue pondering functions of storytelling he finds this state "(...) self-defeating to talk about (...) instead of just up and doing it." (38) The issue of storytelling also becomes obvious through the dialogue of the narrator's voices referring to reception aesthetics: "Die eine Stimme des Erzaehlers in "Title", die die Ueberhand gewinnt, plaediert denn auch mit sich steigernder Eindringlichkeit dafuer, (...) dass das Erzaehlen, wenn es nicht an der eigenen Dauerreflexion zugrunde gehen will, sich auf den Menschen und seine emotionalen und psychischen Beduerfnisse zurueckbesinnen muss.“ (39) Storytelling will have to reverse to man's emotional and psychical needs, the message seems to be. By means of syntactic congestion - "And that my dear is what writers have got to find ways to write about" - (40) the narrator's knowledge is illumined. (41) With that, the very crucial issue of literature's sole depiction of its own metafictionality is anticipated directly in the text.

The issue of self-expression coins the whole collection of stories. In its title story, "Lost in the Funhouse", (42) thirteen-year-old Ambrose finds himself in a maze in a theme park; he got lost. This seems to lead to Ambrose's experiencing of his self; yet while reflecting, Barth has the 
story interrupted by comments on narrative functioning: “(...) a pretty girl and exquisite young lady, who lived not far from them (...) in the town of D_, Maryland. Initials, blanks, or both were often substituted for proper names in nineteenth-century fiction to enhance the illusion of reality." (43) Such statements do not appear incidentally but are put at the center of interest whereas fictional events in the story get in background. As lost as Ambrose is in his maze the narrator is in his own story. Again storytelling itself is representative of the matter the narrator tries to communicate. $\mathrm{He}$ is as conscious of his issue as his protagonist is conscious of himself.

In "Water-Message", (44) Ambrose again is searching for experience. A little older now, he is in an inner and outer maze. On a beach he finds some bottle with a paper inside that reads: "TO WHOM IT MAY CONCERN YOURS TRULY'. (45) The 'actual' message deliquesced, only address and salutation have remained. Whereas 'et cetera' in "Life-Story" and 'blank' in "Title" substituted the blank, now the blank itself emerges.

As last reference, "Menelaiad" is to be drawn upon. (46) Here, Barth has direct and indirect speech meld into a newly dimensioned structure. Menelaus, pushing his wife Helen to white heat by not cease asking why she loves him, eventually loses her; by that Helen sparks off the Trojan War. The story within the story here is pushed to the seventh degree with Menelaus telling about telling Nestor's and Ulysses' sons about telling Helen about telling Proteus about telling Proteus' daughter - and so on - how he destroyed their love. The Ambrose stories appear almost realistic compared to this no-holds-barred fashion of inverse storytelling.

The latter stories of the collection Lost in the Funhouse appear detached from the settings of the earlier stories of the collection. The narrators in the latter stories appear older. While issues of being are in the foreground in the earlier stories, in the latter stories Barth immerses himself in issues of writing and the creation of art. The narrators of the latter stories appear even more self-reflecting; they dedicate themselves to timeless and eidetic topics - whereas Ambrose in the earlier stories has to make experiences he afterwards will have to deal with.

Given the topic of the blank is not in foreground Barth enhances the topic of infinity. As to the very first story that is cited over and over again, in the shape of the topic of love endless repetition comes out into view. Just like in "Menelaiad", where several transmission levels are distorted toward non-comprehensibility, Ambrose's mirror image in being "Lost in the Funhouse" is dissipated in an infinite number of single images, confronting him with an "(...) endless replication of his image in the mirrors (...)." (47) In Ambrose concluding to become an artist Barth hints at the absurdity of the world that can only be faced by creating a 'counter-world'. "Life-Story" has the grown-up artist reflect on that 'counter-world', assuming himself as part of it.

"Both the forms of existence and the forms of fiction are most satisfying when they are in harmony with their essential qualities. But because these forms exist in time, they cannot persist unchanged without losing their harmonious relationship to the essence of being and the ideas of fiction." (48) This is what Barth in his short stories is about; his experimental approach attempts merging of presence of action and presence of telling in order to depict the very issue of imitation in the fiction of forms. The analogy with the deconstructionist approach in referring to its infinite referring of one text to another (49) is obvious. The breaking up of passed-on ways of storytelling leaves the reader unable to decide whether witnessing the reflections of the narrator or of the protagonist ("Lost in the Funhouse"). When Barth constantly has the narrator's situation refer to Ambrose, or the author-narrator ("Life-Story") is about to become one with his own work of art, traditional reader reception is challenged. Ambrose's image as is dissipated in the mirrors remains a multi-reflected image; its details make for the "Life-Story" of the author-narrator, and all imitations in the forms of fiction establish one fiction - the fiction that is prized open to be reflected by metafiction.

\section{Acknowledgment}

This is a slightly revised version of an unpublished essay first drawn up in 1993. My special thanks to Karl Schubert, $\mathrm{PhD}$, University of Heidelberg, for putting Barth on the list.

\section{References}

[1] Goeller KH, Hoffmann G (1972). Die amerikanische Kurzgeschichte. Duesseldorf: Bagel, pp. 16-20.

[2] loc. cit.

[3] Kostelanetz R (1972). Notes on the American Short Story today. In: Bungert H (ed.). Die amerikanische Short Story. Theorie und Entwicklung. Darmstadt: Wissenschaftliche Buchgesellschaft, p. 355.

[4] Kostelanetz, p. 359.

[5] Kostelanetz, p. 362.

[6] loc. cit.

[7] Scholes R (1979). Fabulation and Metafiction. Urbana: University of Illinois Press, p. 106.

[8] loc. cit.

[9] Scholes, p. 108.

[10] loc. cit.

[11] Scholes, p. 109.

[12] Barth J (1968/1989). "Life-Story” In: The Norton Anthology of American Literature, Vol. 2. Ed. by Nina Baym, Ronald Gottesman, Laurence B. Holland, David Kalstone, Francis Murphy, Hershel Parker, William H. Pritchard, Patricia B. Wallace. New York: Norton, pp. 2144-2152.

[13] Barth, p. 2146. 
[14] Barth, p. 2145.

[15] Ziegler H (1987). John Barth. London/New York: Methuen, p. 16.

[16] Barth, p. 2145.

[17] Arlart U (1984). "Exhaustion" und "Replenishment": Die Fiktion in der Fiktion bei John Barth. Heidelberg: Carl Winter, p. 26.

[18] Barth, p. 2148.

[19] Robbe-Grillet A (1963). Pour un nouveau roman. Paris: Edition de minuit, p. 15-23. Cp. Arlart, p. 26.

[20] Cp. Schaefer T. (2009). Positionen literarischer Dekonstruktion. Paul deMan und Jacques Derrida. Marburg: Tectum.

[21] Ricardou J (1967). Problèmes du nouveau roman. Paris: Editions du seuil, p. 61, p. 184. Cp. Arlart, p. 26.

[22] Cp. Egloff G (2010). Bret Easton Ellis: Die Krise des Virtuellen - das Virtuelle der Krise. Literarischer Abgesang auf den Konsumkapitalismus der Jahrtausendwende. In: Nielsen B, Kurth W, Reiss HJ, Egloff G (eds.). Psychohistorie der Krise. Heidelberg: Mattes, pp. 151-170; cp. Egloff G (2001). Der einsame Beobachter bei Fitzgerald, Salinger und Ellis. Individuum und Gesellschaft im US-amerikanischen Roman des 20. Jahrhunderts. Marburg: Tectum.

[23] Barth, p. 2147.

[24] loc. cit.

[25] loc. cit.

[26] loc. cit.

[27] loc. cit.

[28] loc. cit.

[29] loc. cit.
[30] Ziegler, p. 49.

[31] loc. cit.

[32] Barth, p. 2150.

[33] loc. cit.

[34] loc. cit.

[35] loc. cit.

[36] Barth J (1968/1988). “Title” In: Lost in the Funhouse. Fiction for print, tape, live voice. Garden City/New York: Anchor/Doubleday, pp. 105-113.

[37] Barth, p. 111.

[38] loc. cit.

[39] Arlart, p. 47.

[40] Barth, p. 113.

[41] Cp. Arlart, 47.

[42] Barth J (1968/1988). "Lost in the Funhouse" In: Lost in the Funhouse. Fiction for print, tape, live voice. Garden City/New York: Anchor/Doubleday, pp. 72-97.

[43] Barth, p. 72.

[44] Barth J (1968/1988). "Water-Message" In: Lost in the Funhouse. Fiction for print, tape, live voice. Garden City/New York: Anchor/Doubleday, pp. 40-57.

[45] Barth, p. 56.

[46] Barth J (1968/1988). "Menelaiad" In: Lost in the Funhouse. Fiction for print, tape, live voice. Garden City/New York: Anchor/Doubleday, pp. 130-167.

[47] Barth, p. 94.

[48] Scholes, p. 107.

[49] Schaefer T. (2009). Positionen literarischer Dekonstruktion. Paul deMan und Jacques Derrida. Marburg: Tectum, p. 87. 